\title{
Queenship in Kush: Status, Role and Ideology of Royal Women
}

\author{
ANGELIKA LOHWASSER
}

In the ancient Mediterranean world, the exceptional status of queens in the Kingdom of Meroe inspired comment in the works of GrecoRoman writers. These women, and the kandake in particular, continued to attract the attention of travelers and scholars down into modern times. By comparison, the role and status of their predecessors, the royal mothers, wives, sisters, and daughters, from the Kushite 25th Dynasty down through the Napatan Period to the reign of Nastasen, remained little known. ${ }^{1}$

Beginning with George A. Reisner's excavations of the royal cemeteries at El Kurru and Nuri and Francis Ll. Griffith's work at Kawa, a steadily increasing body of material has become available for the study of Kushite "queenship." These sources fall into three categories:

1) inscriptional, ranging from lengthy royal texts on stelae from Napata and Kawa to the labels accompanying representations of royal women and inscriptions on objects (primarily burial equipment);

2) representational, viz. the depictions of royal women on stelae and temple walls;

\footnotetext{
${ }^{1}$ This background information is expanded upon and documented in "Die königlichen Frauen im antiken Reich von Kusch," Meroitica 19 (2001), the full publication of my dissertation entitled "Die königlichen Frauen von Kusch (25. Dynastie bis zur Zeit des Nastasen)." The most important theses and conclusions of that work are presented here. Many recent studies have dealt with aspects of Kushite and Meroitic queenship in various contexts; they are duly considered below. But none of them has been devoted in its entirety to investigating the phenomenon of Kushite queenship per se, the goal of my monograph.
}

3) archaeological: tombs and associated burial goods in the cemeteries of El Kurru, Nuri, Meroe, and Abydos.

In Meroitica 19, these data are presented in catalogue form, providing the basis for the conclusions which are summarized below. A second catalogue lists all those royal women whose names are known; each entry includes variant orthographies for the name in question, the titles, epithets and filiation of the woman, her documentation and a commentary. Analysis of these varied sources demonstrates the crucial role played by queenship as the indispensable counterpart of male kingship in Kushite ideology.

\section{Royal Women in Society}

A royal woman's epithets and filiation, as well as her costume and regalia, provide information about uniquely Kushite features of her status.

The titles and epithets documented for Kushite royal women are few, especially in comparison to the wealth of such designations borne by their pharaonic Egyptian counterparts, ${ }^{2}$ Titles which document a sacral role include $h m t n t r$ (priestess), jhjjt (sistrum player)', śhmijt (sistrum player), hnnw (sistrum player), and hmt nt $r$ (God's Wife). None of these sacral titles is specified by the addition of a deity's name, by contrast to ancient Egyptian practice. Even in those cases where it is clear that the god served was Amun

\footnotetext{
${ }^{2}$ For convenience's sake, I have adopted the English renderings employed by Troy (1986) for all but a few titles and epithets below. For detailed discussion of specific terms, see Meroitica 19.
} 
(as, for example, in the case of the sistrum player Matiqen ${ }^{3}$ ), this association is not explicit in the title.

Some titles imply a specific status at court: $j r j-p^{c} t t$ (noblewoman); tpjt $n$ ḥm.f (first great wife of his majesty), rht njśwt (king's acquaintance), hnwt hmwt nbwt (lady of all the women). Others are analogous to king's titles expressing dominion: hnwt $t 3 w j(\mathrm{tm}) / \mathrm{nbt} t 3 w j$ (lady/mistress of the [entire] Two Lands), hnwt $\breve{s}^{c} w$ mhw (lady of

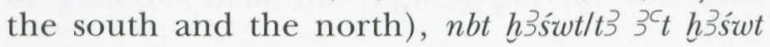
(mistress/the great one of the foreign countries), hnnwt kmt/kJ̌šl $t 3$ śtj (lady of Egypt/Kush/ Nubia), s $3 t r^{c}$ (daughter of Re, as the feminine counterpart of "son of Re" designating the king). These titles were used in parallelism with those of the king. Royal women are defined as sharing the power to rule, the feminine equivalent of the king. Effective influence associated with such titles should not be over-rated, but they do express the ideal of complementarity (for which, see below). Since the titles sist nt $\underline{r}$ (daughter of the god) and mwt ntr (mother of the god) are both documented only a single time, their import remains unclear.

The majority of epithets borne by royal women express the esteem in which they were held, or refer to agreeable characteristics. Most such epithets go back to the Old Kingdom in pharaonic Egypt, and they are especially common in the New Kingdom and in Dynasties XXV and XXVI. They include wrt hśjw (great of praises), bnrt mrwt (sweet of love), wrt/nbt j3mt (great one/mistress of loveliness). (Epithets documented only a single time for Kushite royal women are śhtp njśwt $n \underline{h} r t$ hrw (one who satisfies the king with [his] daily needs), śn $\underline{d} m$ jb hr $m \underline{d} d t . s$ s $n$ (one who sweetens the heart of Horus [i.e., the king] with all her words which are said), $\underline{h} n m t h^{c} n \underline{t} r$ (one who is united with the limbs of the god), $j 3 m h r j b h r . s$ (beloved in the heart of her Horus [=lord]), hlkrt $n j s ́ w t w^{c} t$ (sole ornament of the king), špśt njśwt $w^{c} t$ (sole noblewoman of the king).) The expression rmt $n \mathrm{kmt}$, "inhabitant of Egypt" (sometimes abbreviated simply $r m \underline{t}^{4}$ ) would seem to refer to

\footnotetext{
${ }^{3}$ So in the text of the Adoption Stela of Henuttakebit (Schäfer 1895).

${ }^{4}$ Note that Priese (1968: 190-91) believes the word in question is not to be read $r m \underline{t}$, but qore, the Meroitic word for king/queen.
}

the origin of the women who bear the epithet, but since it is also associated with women who have Kushite names, its effective meaning remains unclear.

\section{Kushite Queens as Represented in Art}

As a rule, pharaonic Egyptian costume and regalia were adopted for the depiction of Kushite kings, although certain specifically Kushite features make identification of them as Kushites unproblematic. ${ }^{5}$ Kushite queens, however, look much less "Egyptian" than their male counterparts. ${ }^{6}$ Except for the vulture headdress, the double-feather crown, and the double-feather crown with sun disc and cow horns (which was already modified and "Meroiticized" in the early Napatan Period), there are no Egyptian elements.

A large shawl was wrapped around the body below the armpits or around the hips. A second shawl which could be fringed or decorated with woven stripes was worn over the first. Sometimes women draped a sash over the shoulder. A small tab-like element hangs below the hem of a dress to reach the ground (fig. 1). This diagnostic element has been described as a "little tail." Sometimes there are fine ridges on its surface; the cases are few where it simply resembles a line.

Hofmann (1971: 49-51) interpreted the "little tail" as a kind of "badge of honor" first associated with Taharqa's mother; she also believed it identified a woman as a kandake in later times. However, this iconographic feature is not restricted to depictions of royal women. ${ }^{7}$ Granted, the bull's tail of kingly regalia was inappropriate for a woman; nevertheless, the "little tail" is indeed reminiscent of an animal's tail. The bushy shape, which occurs in most depictions, and the

\footnotetext{
${ }^{5}$ See Russmann 1974: 11-44; Kushite features include a ram's-head amulet, rams' horns, double uraeus, and "southern" physiognomy.

${ }^{6}$ Contra Hofmann, 1971: 49; for detailed consideration of the costume and regalia of Kushite queens, see Lohwasser 1999.

${ }^{7}$ Examples of non-royal women with this attribute include: stela Louvre E 13073 (Munro 1973: pl. 28, fig. 101; stela Leiden XIV, 13 (van Wijngaarden 1932: pl. IV.13); coffin of Kheriru from the Asasif (unpublished; I am indebted to Dr. E. Haslauer for providing access to photographs of this piece); stela of Pasalta (Dunham 1963: fig. 220).
} 


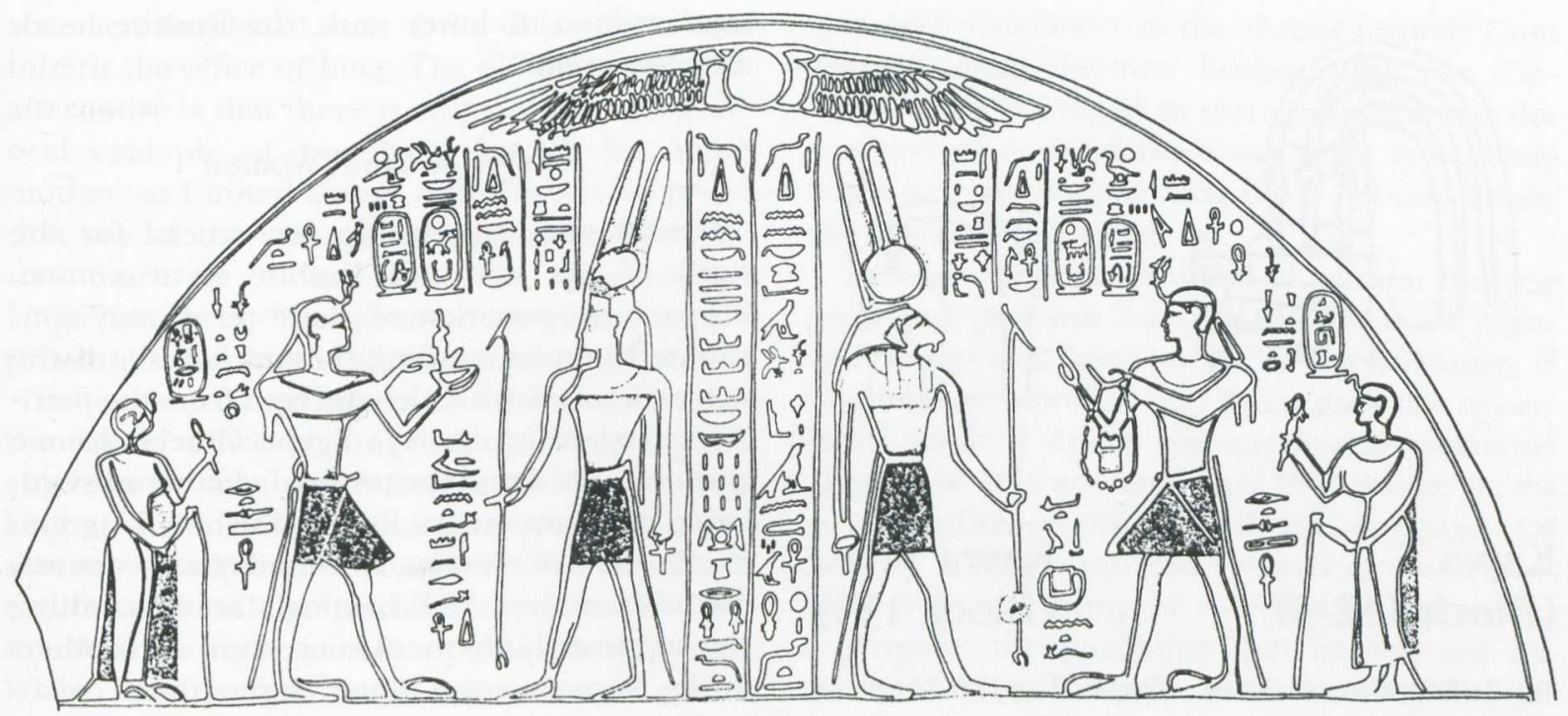

Fig. 1. Dream Stela of Tanwetamani (after Grimal 1981a: pl. I).

ridges, which could have been intended to imitate the appearance of fur, can be cited in favor of this proposal.

In ancient Egypt, animal tails tied around the arm at the elbow were considered typical for depictions of Nubians. ${ }^{8}$ In officials' tombs of the New Kingdom, Nubian chieftains in tribute scenes are depicted with animal tails suspended from their arms or waist. Paintings in the tomb of Kenamun (TT 93) include the depiction of a statue of Amenhotep II as a Nubian wearing animal tails at his elbow. ${ }^{9}$ Nubian women, too, wore animal tails: in the tomb of Tutankhamun's Nubian viceroy Huy (TT 40) a Nubian woman is shown with an animal tail tied around her arm. ${ }^{10}$ Since all these examples show the animal tail(s) worn on the arm, the depictions of Nubians wearing a tail below the knees in the tomb of Tjanuni (TT 74) are exceptional. ${ }^{11}$ The wearing of decorative amulets (though not tails) at the calves is also known from representations of Nubians in the New Kingdom. Finds from Sayala that date to the Christian era support this evidence; two

8 Török 1990: 172.

${ }^{9}$ Davies 1930: 26, pl. XVII.

${ }^{10}$ Davies/Gardiner 1928: pl. XXX.

11 Drenkhahn 1967: 27; Brack/Brack 1977: pl. 32; Decker 1991: 98-99, fig. 2. skeletons excavated there had fringe tied to the knees. ${ }^{12}$ Nowadays among various African peoples-for example, the Nuba-there is the custom of wearing feathers and parts of pelts, perhaps also animals tails, below the knee.

Possibly Kushite women tied an animal tail, as an amulet insuring fertility, to their knee or calf, and it hung down below the dress worn over it. I suggest that the animal in question was a fox. Fox tails are universally associated with eroticism and fertility. The ancient Egyptian hieroglyphic sign used to write words associated with birth depicted fox pelts bound together. ${ }^{13}$ Amulets were made in the form of this sign. ${ }^{14}$ The foxtail would thus represent the "feminine" pendant to the "masculine" bull's tail of the king which has also been interpreted as a fertility symbol.

The wigs worn by Egyptian royal women exhibit considerable variety. By contrast, Kushite women did not wear wigs. Depictions of their natural bobbed hair are sometimes detailed to show small, tight curls. ${ }^{15}$ In one of the depictions of Wedjarenes and in the sole representation of

\footnotetext{
12 Bietak/Schwarz 1987: 136, no. 76706, pl. 49.

13 Borchardt 1907: 75-76; Jéquier 1921: 93-94.

${ }^{14}$ De Morgan 1903: pl. V no. 29; Vernier 1927: pl. LXXXII.

${ }^{15}$ Staehelin 1966: 178-79; Drenkhahn 1967: 77.
} 


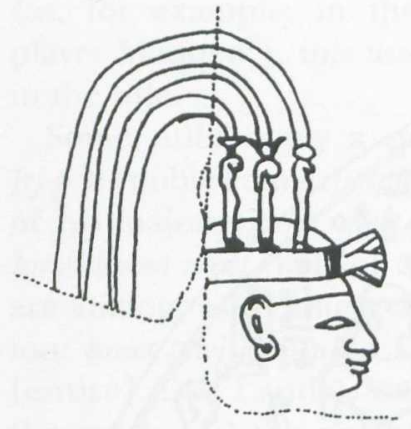

Kawa T (Block 112-3)

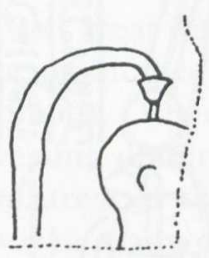

Kawa T (Block 135)
Fig. 2. Princesses at Kawa, Temple $T$ (after Macadam 1955, pl. $64 e-i)$.

Meritamun, little braids hang down from the back of the head to the neck, terminating in decorative little tassels or tiny beads. ${ }^{16}$

Kushite royal woman are seldom depicted wearing the vulture headdress. Often a fillet that served to secure a lotus blossom at the forehead and/or a uraeus was tied around the head. The most frequently documented headgear consists of double plumes with sun disc and cow horns. The headdress is short and squat by comparison to its Egyptian prototype.

The "Kushite headdress," unusual headgear known only from representations of Kushite women, consists of as many as four components, shaped like tiny figures of goddesses or papyrus umbels, attached to a fillet. Band-like elements spring upward from these "supports" to arch down over the back of the head (fig. 2). Perhaps the "bands" are intended to depict feathers. ${ }^{17}$ Hofmann (1977: 109) would interpret this headgear to identify a member of the royal harim. Kendall, also, presumes that different kinds of headdresses reflecting differing status among royal women. ${ }^{18}$ Only royal women of higher rank were entitled to wear crowns and the uraeus; for

\footnotetext{
${ }^{16}$ For this headgear and its occurrence in the costume of non-royal women see Russmann 1997: 31-35.

${ }^{17}$ Nuba women wear a similar feather headdress; cf. e.g., Bernatzik 1930: 196, 198.

18 1982: 25; so, too, Török 1995: 116.
}

royal women of lower rank, the Kushite headdress was used.

\section{Status of Royal Women}

Designations of kinship are crucial for the study of the status of Kushite royal women. Proper interpretation of these terms may contribute to understanding the mechanism of the succession in Kush which differed from the patrilinear system in dynastic Egypt. Graeco-Roman authors considered the unusual manner of regulating the succession in the Kushite kingdom exotic, and it remains to this day a frequently discussed subject. M. F. Laming Macadam, noting the supposedly frequent succession of brothers in the Napatan royal house, argued for a collateral system-i.e., that the throne passed from brother to brother, until the generation was exhausted. ${ }^{19}$ According to this theory, the person who was entitled to succeed the last brother was the oldest son of the oldest brother, followed then by his own brother and so forth. However, there is only one unequivocal case of a brother following a brother: Aspelta who succeeded Anlamani, both sons of Nasalsa.

Karl-Heinz Priese (1981) favors the idea that the succession was matrilinear - that the throne passed from one king to the next through a woman, usually the sister. (This scheme does not envisage women assuming the throne.) Recently, Laszlo Török (1995: 107-14; 1999: 28081) attempted to establish a patrilineal model, with the throne passing from father to son. However, he acknowledged a "female succession line," with female candidates bearing specific "cult" titles such as bnrt mrwt and nbt j3mt.

The matrilineal component seems especially significant to me. In matrilineally organized societies the person who can bestow an office is always female ${ }^{20}$ Normally this woman is the sister of the ruler. She bequeaths the right to the throne to her children. Her male children can assume the office while the females inherit the right to pass on the office. There are three scenarios that can result from this system; for the Kushites, Priese (1981: 50, fig. 1) prefers the

\footnotetext{
${ }^{19}$ Macadam 1949: 124.

${ }^{20}$ For matrilinearity in general, see Buchler 1980.
} 
scheme whereby all sons of the oldest sister may inherit the office of king. The difficulty with this alternative is that there is only a single unequivocal example of two kings having the same mother, as I noted above. And there is no proof that any of the women involved were oldest sisters. Since we do not know the names of all kings' mothers, the prudent model, for the present, is simply "the sons of sisters inherit."

In the matrilineal system, the first ancestor for the "male" office of king is male. The original chieftain or ruler was male, just as the reigning king is male. Alara is the person who is consistently cited from Dynasty XXV onwards as the founder of the Napatan royal line. ${ }^{21}$ Presumably the right to rule originated with him. When Taharqa cited the female ancestors of his mother who were Alara's sisters, he emphasized the Napatan system of matrilineal descent through the mother. The possibility to pass on the right to the throne was transferred from Alara to his sisters who then bequeathed this power to their children. The female ancestors who were important for the king to claim rulership traced their lineage back to the sisters of Alara. For this reason they were especially revered. ${ }^{22}$ Priese (1981: 52) would derive additional evidence from the Assyrian source which calls Tanwetamani the son of Taharqa's sister. Here, too, the right to the throne passed through a sister (sint) to the "son of a sister." Whether Taharqa's sister or rather a titular royal sister (śnt njśwt) was in actuality the mother of Tanwetamani remains moot.

Evaluating all available sources and differing interpretations of them, it seems to me most likely that the sint njśwt could pass on the right to the throne. I would suggest that all sisters were equally entitled to bequeath kingship to their sons. All women who bore the title śnt njśwt belonged to a specific category, the śnwt njśwt; their sons formed the pool of snw njsist. The daughters of these women in turn were snwt $n j s i \omega t$ and so on. The frequently mentioned sn w njśwt (king's brothers) comprise the group of

${ }^{21}$ Note, however, that Priese (1970: 23) takes exception to this view, calling attention to the fact that Aspelta traced his ancestry two generations back beyond Alara.

22 Taharqa established a cult for the mww.t tpjw ${ }^{c}$ (Kawa VI, 25) while Anlamani placed his mother under the special protection of the gods (Kawa VIII, 26). potential successors to the throne, equals from among whom the new Kushite king was chosen. ${ }^{23}$ They belonged to this group because the mothers of each of them was a śnt njśwt. Only when her son became king did a śnt njśwt attain the status of mwt njsist.

In Kush there are a series of women bearing both hmt njśst and snt njśwt titles who are regularly designated "sister-wives" in the literature. If one admits, however, that śn/śnt does not necessarily imply a direct consanguineous relationship, then it is not necessary to presume incest or a legitimacy through sibling marriage. Of course, a king chose his consort(s) when possible from the group of snt njśwt. In the model I propose, the possibility that he selected his actual sister was comparatively remote. Should he marry a snt njśwt, then all of his sons were potential successors.

The genealogy of Aspelta furnishes the most important documentation of the matrilineal component in the succession. ${ }^{24}$ The legitimacy of Aspelta's selection was based on his descent from seven successive generations of snwt njśst. Each of these seven women might have been a decisive factor in the succession of kings between Alara and Aspelta. In the literature they are customarily called mothers of kings or crown princes, but this is an interpretation which ignores the fact that only for the first of them, Nasalsa, is the title $m w t$ njśwt actually mentioned. The omission of the title $m w t$ njswt for the others cannot be coincidental, especially since śnt njśwt is consistently included in their titularies. For this reason, I do not believe that any of these seven women except Nasalsa was the mother or wife of a king. The fact that the king was selected from among a group of possible successors does not necessarily imply thạt all women in the female line of descent were wives or mothers of kings.

Aspelta's genealogy documents his "pure" lineage by noting that seven generations of his female ancestors were sint njśwt (fig. 3); they all belonged to that group of women who might

${ }^{23}$ Previously remarked by Apelt (1990: 28).

${ }^{24}$ Recorded in the text of his Election stela, in the Egyptian Museum, Cairo, JE 48866: Grimal 1981a: pls. V-VII. For a translation see FHN I: 232-52. 


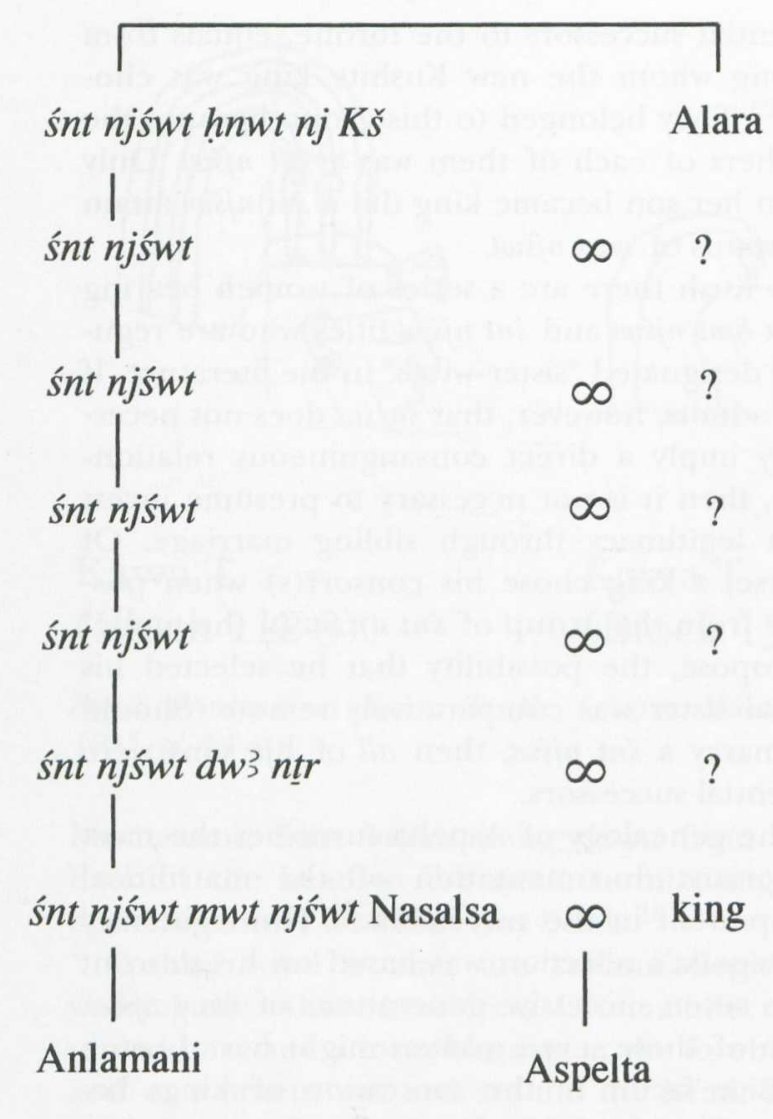

Fig. 3. The genealogy of Aspelta according to the text of the Election Stela.

bequeath the right to the throne, substantiating the legitimacy of his selection. Aspelta thus belonged to the pool of snw njśwt, and, moreover, his association extended back through time over seven generations.

\section{The Evidence of the Tombs}

The tombs of female members of the Kushite royal house are an important source of information about their status. Many of these women were buried in the necropolis of El Kurru and Nuri, like the Kushite kings. ${ }^{25}$ A few royal women possessed tombs in the cemetery of Meroe, ${ }^{26}$ and tombs belonging to Kushite royal women have also been found in Egypt, at Abydos. ${ }^{27}$ Since, however, the minimal remains at Meroe

\footnotetext{
${ }^{25}$ Dunham 1950; 1955.

${ }^{26}$ Dunham 1924; 1963.

${ }^{27}$ Leahy 1994
}

and Abydos preclude proper analysis, the discussion that follows necessarily focuses on evidence from El Kurru and Nuri.

El Kurru is the oldest Kushite royal burial ground. Here lie the so-called ancestral tombs and those of the kings of Dynasty XXV, with the exception of Taharqa. He built his pyramid at Nuri where his successors of the Napatan Period down through Nastasen were also interred. Two wadis divide the cemetery of El Kurru into three sections. The main section is in the center; there lie the tombs of the "ancestors" and those of the kings of Dynasty XXV, as well as the pyramid of an anonymous king dating to the late Napatan Period. In the section to the south, there are six pyramids belonging to royal women of Dynasty XXV and an anonymous pyramid for a queen of the Napatan Period. More tombs of royal women are located in the northern section. In other words, royal women were buried in two groups in the El Kurru necropolis, south and north of the kings' tombs in the central field. Unfortunately, the site produced only limited inscriptional evidence with a bearing on the relative status of these women. But the location, size and equipment of their tombs provide data that is indicative of a hierarchical distribution of burials within the cemetery.

At Nuri, the pyramids were built on two parallel plateaus. Taharqa's pyramid, Nu.1, occupies the highest point in the necropolis, the promontory of the west plateau, while the pyramids of the other kings are situated on the east plateau. The tombs of royal women are located on the west plateau. They form three groups: the southern group inscribes an arch to the south and west of $\mathrm{Nu} .1$; the second group consists of two parallel rows north of $\mathrm{Nu} .1$; while a cluster of very small tombs to the far north form a third group (fig. 4). More inscriptional information is available at Nuri than at El Kurru; thus it is clear that kings' mothers were buried in the southern group, in the largest tombs of the cemetery. Some women buried in the same sector of the cemetery, however, do not bear the title mwt $n j$ śwt. Perhaps they fulfilled other functions which were the prerogative of women in an especially high position entitling them to burial alongside kings' mothers. Kings' wives were laid to rest primarily in the two rows of tombs north 

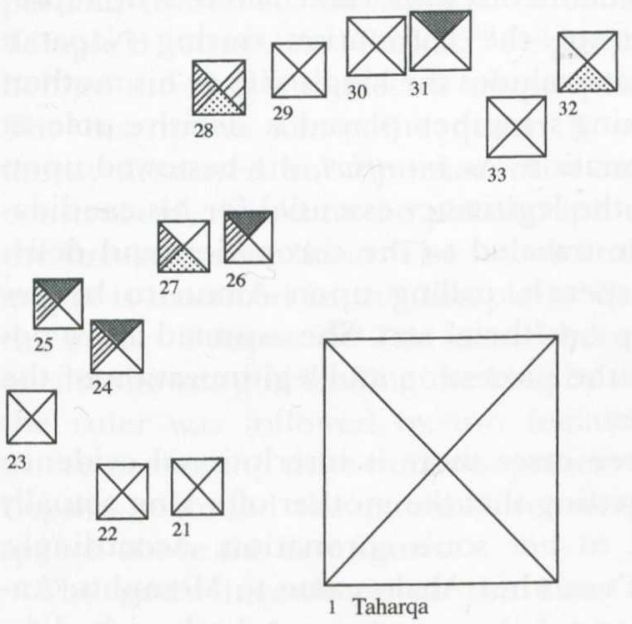

Fig. 4. Female burials in the cemetery at Nuri.

of $\mathrm{Nu}$.1. These women seem to have enjoyed a median status. The tombs forming the group to the north are smaller, and they preserve little textual information with hardly any titles, arousing the suspicion that this part of the cemetery was reserved for royal women of comparatively low status. The form of these smaller tombs can be cited in support of this interpretation. While the tombs of the southern group and those of the two parallel rows possess relatively well-preserved pyramidal superstructures, the small tombs to the north give no indication of ever having superstructures of any kind. The substructures, too, are modest affairs with a single chamber, by contrast to the more complex subterranean arrangements in the other tombs of royal women at the site.

Although the paucity of texts does not permit us to determine the precise status of each individual tomb owner, we can nevertheless postulate that royal women were allotted burial in a particular part of the cemetery according to their status.

With few exceptions, Egyptian royal women of the New Kingdom were not buried alongside the rulers in the Valley of the Kings, by marked contrast to the royal women of Kush who shared the cemetery of the kings. El Kurru and Nuri were reserved for the exclusive use of kings and royal women-mothers, sisters, and wives of rulers. Other male members of the royal family were not given burial there. In the hereafter, as in life, Kushite royal women were not separated from the sovereign.

\section{The Role of Kushite Royal Women in Ritual}

In the cult of the gods, the royal women of Kush, like their Egyptian counterparts, assisted the king by shaking the sistrum. This activity, like censing, was a preliminary to the ritual. Kushite royal women are also depicted pouring libations before Amun, a rite that was the prerogative of the king in Egypt. In Kush it was quite normal to show women libating (e.g., fig. 1). ${ }^{28}$ Pouring liquid-milk or water-was an offering per se, but it might also express a wish for fertility or be associated with purification. The motif of royal women libating makes its first appearance in Dynasty XXV, suggesting that the practice itself was introduced at that time and

${ }^{28}$ In the lunettes of large royal stelae (Tanwetamani: Grimal 1981a: pl. I; Aspelta: Macadam 1949: pl. 40; Harsiyotef: Grimal 1981a: pl. X; Nastasen: Schäfer 1901: pl. I) and on temple walls (Gebel Barkal, B 303; Robisek 1989: 113, 114; Gebel Barkal, B 700: Griffith 1929: pl. V; Sanam: Griffith 1922: pls. XXXVIII, XLV; Kawa: Macadam 1955: pls. 14b, $64 \mathrm{e}-\mathrm{i})$. 
that Kushite royal women actually performed the rite in the cult of the gods. The role of women in the cult took on a new dimension under the Kushites, a dimension which was not open to Egyptian royal women. Kushite queens assumed one of the roles which was reserved for the king in Egypt as "lord of the ritual," vis à vis the god. Kushite royal women not only assisted in preparing for the cult; they participated in the cult, communing themselves with the gods.

\section{Royal Women at the Enthronement}

The most important event, the event which ensured the continuity of kingship, was the enthronement of the new king. In both Egyptian and Kushite ideology, Pharaoh's death plunged the land into chaos. The enthronement of the successor restored order to the universe, ending a period fraught with danger and uncertainty. Festivals served to introduce the new king to the gods whose aid he sought to protect the realm from enemies and misfortune. Royal women were mentioned and represented in association with the coronation ceremony.

In Kush the rite of coronation was symbolized by the tableau "presenting maat, the pectoral and the chain." 29 The new king presented maat in the form of a small figure, ${ }^{30}$ the pectoral and the chain to Amun of Napata (or Amun of Karnak) who handed over crowns to the king in return, as shown on the coronation stela of Piye. ${ }^{31}$ The lunettes of the stelae of Tanwetamani, Harsiyotef, and Nastasen show antithetical renderings of this scene accompanied by texts describing the enthronement of these kings (compare fig. 1). The king is always accompanied by female members of his family-in one scene by his mother and in the other by his wife. It is significant that they assist him on the occasion of this crucial ceremony by shaking a sistrum and libating, exercising priestly functions at this most important moment inaugurating the king's reign. Their presence is not coincidental but purposeful; they were participants in the

\footnotetext{
${ }^{29}$ For details, consult Lohwasser 1995.

${ }^{30}$ From the reign of Harsiyotef onwards maat is no longer included.

${ }^{31}$ Khartoum No. 1851: Reisner 1931: pls. V, VI.
}

ceremony which epitomized Kushite kingship, implying that the feminine counterpart of the king was eminently important. There is no representation of the coronation during Napatan times that excludes the king's wife or his mother.

The king's mother played a decisive role at the coronation. As śnt njśwt, she bestowed upon her son the legitimacy essential for his candidature. She traveled to the coronation and delivered a speech, calling upon Amun to bestow rulership on "their" son. She assumed a key position in the succession and legitimization of the new ruler.

In three cases there is inscriptional evidence for suggesting that the mother of a king actually traveled to her son's coronation. Accordingly, Taharqa's mother Abalo came to Memphis; Anlamani and Irikamanote were both visited by their mothers in Napata. ${ }^{32}$ The texts mentioning these journeys associate them with the myth of Isis and Horus. Whether the journeys occurred in actuality cannot be proven. But the very mention of them documents the importance for the king of his mother's presence at his side for or shortly after his coronation. The texts testify to a tradition that the king's mother should see him newly crowned.

Four sources can be cited in support of the idea that the king's mother and/or his wife delivered an address on the occasion of the coronation. This speech was not a formulaic recitation, but an address couched in individual terms, even if the content was in essence uniform. The royal woman requested that Amun bestow the rulership on the new king, that the god "establish" him as king. The fullest version of the speech is recorded for Nasala on the lunette of Aspelta's Election Stela. ${ }^{33}$ It is inscribed in the center of the lunette, occupying the most prominent position available. Another example of this speech was found in Temple B 300 at Gebel Barkal, room $303^{34}$ where the text begins following on the label identifying the king's mother Abalo and

\footnotetext{
32 Taharqa: stelae Kawa V, 1. 16-21 and Tanis, 1. 11-22 (Macadam 1949: pls. 9, 10; Leclant/Yoyotte 1949: pl. II); Anlamani: stela Kawa VIII, 1. 22-24 (Macadam 1949: pls. 1516); Irikeamanote: inscription Kawa IV, 1. 81-84 (Macadam 1949: pl. 25).

33 Grimal 1981a: pl. V.

${ }^{34}$ Robisek 1989: 113-14.
} 
continues after the label of the king's wife Takahatamani. The two remaining examples are only partially preserved. On the wall of court 502 in Temple B 500 at Gebel Barkal, ${ }^{35}$ Pekereslo stands behind the king who faces a barque procession. The inscription above the queen is nowadays mostly destroyed but a portion of it can be reconstructed, thanks to the photograph taken by the Breasted expedition. The fourth and last example is inscribed in the Temple of Sanam, in the shrine of Aspelta. ${ }^{36}$ The scene where the text occurs shows a god leading the king by the hand; the ruler was followed by two female figures whose names and titles were not preserved when Lepsius recorded the minimal remains of the speech above the first figure.

The god's investiture of the king was not taken for granted-at the very least there was a ritual requirement, perhaps of great antiquity, that a woman of the royal house must request the office of rulership from Amun.

\section{Egyptian Influence}

The royal women of Kush and Egyptian queens both had their own, discrete traditions which limit the viability of comparisons between them. Direct borrowings from Egypt can be detected in the representations, but the adoption of iconographic features was, however, relatively limited and not comparable to the frequent and notable adoption of Egyptian queenly titles and epithets. Structural similarities are noteworthy, especially in respect to the hierarchy within the set of royal women where, e.g., the king's mother occupied the most important position in both cultures. The roles played by royal women in Kush, however, followed their own tradition which had few parallels in Egypt. The only example of congruence is the office of "God's Wife" which was important for the ideology of Kushite rulership in Kush, as well as for the Kushite pharaohs of Dynasty XXV in Egypt.

I concur with those scholars who have argued that the person who arranged for the adoption of Amenirdis I by the incumbent God's Wife Shepenwepet I (daughter of Osorkon III) was

\footnotetext{
35 Priese 1968: 177, n. 70.

36 Griffith 1922: pl. XLV.
}

her father Kashta, not her brother Piye. ${ }^{37}$ In subsequent adoptions, the adoptee was always the daughter of the reigning king. Since Kashta probably did reach Thebes, ${ }^{38}$ it would seem to have been politically opportune for him to arrange his daughter's adoption. The text of Piye's victory stela records the injunctions:

When you reach Thebes opposite Karnak, enter into the water, purify yourselves in the river, and dress yourselves. Lay down your weapons! Loosen your arrows! ${ }^{39}$

In other words, Thebes should not be attacked but treated as a sacred place. The text repeatedly alludes to Amun of Karnak as the king's supporter. There are grounds for supposing that Piye did not need to conquer the Theban region, quite possibly because Kashta had already completed Thebes's pacification. As a manifestation of his power, he might well have proposed that Shepenwepet adopt his daughter. Thus Piye would have found an ally, rather than an opponent, a person whom he could count upon as a security factor in Egypt's south.

In the tradition of her predecessor and adoptive mother, Amenirdis I utilized her position as God's Wife to political advantage. From this time forward, God's Wives exercised royal rights in an expanded ritual role, although de facto power probably lay in the hands of the major domos who administered their property. The ascendancy of the institution of God's Wife began towards the end of the Third Intermediate Period, but its full flowering was first possible in Dynasty $\mathrm{XXV}$, thanks to the largely peaceful environment of the reunified country and to the traditionally important role of Kushite royal women.

Contact with the state god Amun was maintained primarily through these women. According to texts preserved on two stelae of Taharqa, ${ }^{40}$ the (mythical) origin of the relationship between the Kushites and Amun was established by a

${ }^{37}$ Bierbrier (1975: 102), Robins (1993: 154), Török (1995: 51) and Morkot (1999: 196). Contrast Kitchen (1995: 151) who favors her brother Piye.

38 So Priese 1970: 21.

${ }^{39}$ FHN I: 71.

${ }^{40}$ Kawa IV, 1. 16-19 and Kawa VI, 1. 22-25 (Macadam 1949: pls. 7-8, 11-12). 
"contract" between the god and the Kushite royal house. This arrangement was strengthened by the presentation of royal women to Amun, the sisters of the royal ancestor Alara.

The institution of God's Wife provided the Kushites in Egypt with a means to express their own concept of rulership and the role of women in it. The office of God's Wife was the instrument that allowed Kush to manifest Kushite "queenship" in Egyptian guise in Egypt itself. There God's Wives were exclusively associated with Amun. They were the mortals with the closest contact to their divine consort. In their own kingdom, Kushite royal women were regularly depicted alongside the king, but in Egypt this was not common during Dynasty XXV. Instead the God's Wife accompanied the Kushite king, for she provided an acceptable alternative for both Egyptians and Kushites.

\section{The Ideology of Queenship as Expressed in Religion}

The roles of Kushite women were equated with those of goddesses, "thematized" and interpreted sacramentally. ${ }^{41}$

Many sources document a maternal role for goddesses in their relationship with the king. Goddesses could be shown engaged in maternal activity while texts describe goddesses as the king's mother. A particularly intimate expression of the mother-son relationship is the act of nursing. Through nursing, a mortal is imbued with the essence of royalty; he is drawn into the divine sphere, "sacralized." In Kush the nursing goddesses were Mut, Bastet, and Isis. ${ }^{42}$

Isis enjoyed a special status among mother goddesses as the mother of Horus. Because Horus is the living king, Isis is also closely associated with kingship. The myth of Horus and his loving mother Isis is frequently found in Kushite sources, with the king's actual mother compared to Isis and her son to Horus.

\footnotetext{
${ }^{41}$ For the concept "sakramentale Ausdeutung," see Assmann 1977: 21.

${ }^{42}$ Mut: aegis of Kashta (Leclant 1963: figs. 2-5); Bastet: menat of Taharqa (Leclant 1961: pl. I) and in the text of the Nastasen stela, 1. 32-33 (Schäfer 1901: 114); Isis: amulet of Neferukakashta (Dunham 1950: pls. LXc, LXXb4/1).
}

Different goddesses assumed the role of consort for different forms of Amun. Generally, Amun of Karnak, Amun of Napata, and Amun of Sanam were all associated with Mut, the goddess known from Egypt as Amun's partner. Her primary function was to accompany the god. She stands behind him, protecting or simply accompanying him and accepting offerings with him. The presence of his divine wife makes the state god Amun universal.

Goddesses occur in Kush primarily in two functions: as mothers and as companions. Royal women are found in precisely these same two contexts. The functions overlap, the divine and mortal spheres thematize the same basic pattern.

\section{Royal Women in the Roles of Goddesses}

The most important role of a queen in Kushite rulership is that of king's mother. She is crucial for her son's claim to the throne. Just as Horus was legitimized by Isis, so the Kushite king is dependent upon legitimation through his mother. The prominent role of the king's mother is apparent at the king's enthronement when she had elementary functions to fulfill (see supra). The king's mother was also specifically associated with Isis. In texts of Dynasty XXV and the Napatan Period, the comparison of Horus and Isis with the king and his mother is a prominent and recurring theme. ${ }^{43}$ It must be emphasized that the same myth does not play a comparable role in Egyptian royal ideology. The Kushites did not simply adopt many concepts of rulership that they encountered in Egypt, as often presumed. Rather, the Kushites purposefully took up individual aspects and adapted them to accommodate their own ideas of rulership and to interpret them sacramentally. The connection between the Isis-Horus myth and the king's mother is the closest point of contact between goddesses and queenship: the real world is projected into the divine sphere and vice versa. Isis as mother and decisive factor for Horus's

43 Taharqa: stelae Kawa V, 1. 19-21, Tanis 1. 16-22 (Macadam 1949: pls. 9, 10; Leclant/Yoyotte 1949: pl. II); Anlamani: stela Kawa VIII, 1. 22-24 (Macadam 1949: pls. 15-16), Khaliut stela 1. 13-15 (Reisner 1934: 43-44), Irikeamanote: inscription Kawa IX, 1. 34-35, 1. 81-84 (Macadam 1949: pls. 23, 25). 
legitimacy is equated with the king's mother who acts as mother and also plays an important role at the coronation of her son.

Just as goddesses stand behind a god, so royal women - wives and mothers of kings - stood behind the king. In particular they accompanied him in tableaus depicting him officiating in the ritual before the gods; in such contexts royal women often participated actively in the cult. As companions they supply the feminine counterpart to the masculine element embodied in the king. Just as the King of the Gods Amun is accompanied by his wife Mut to embody the principle "god" as a whole comprising masculine and feminine elements, so the king is not depicted acting alone as the male ruler but as the masculine aspect of rulership accompanied by his royal wife who manifests the feminine aspect.

The accompaniment of the king by his wife is to be understood as a conscious expression of gender dichotomy. In their role as companions of the king, queens have a special function to fulfill. The importance of both mother and wife is reflected in their antithetical arrangement in the scenes depicted in the lunette of large royal stelae (see, e.g., fig. 1): mother and wife were thematized as companions of the king.

\section{Queenship in Kush}

Down to the present, the only longer study that considers Kushite queenship is Laszló Török's "The Birth of an Ancient African Kingdom: Kush and Her Myth of State in the First Millennium BC” (1995). Török makes frequent reference to Troy (1986), and he interprets Kushite queenship by drawing parallels with the institution in Egypt, as Troy understood it. For her, duality is the fundamental concept underyling Egyptian queenship - sexual duality and generational duality. The former defines the relationship between male and female while the latter encompasses the relationship between mother and daughter.

By contrast, I believe that the concept "complementarity" is better suited to interpreting queenship. Hornung (1971: 233-40) borrowed the term "complementarity" from the natural sciences to explain the juxtaposition of a supreme god and many gods. "Complementarity" describes a relationship between components which can be viewed separately as opposites but which comprise a unified whole when taken together. ${ }^{44}$ In general, complementarity is understood as "parallel complementarity." For example, two concepts such as "masculine-feminine" are designated complementarity.

In Egyptian, as in Kushite queenship, there are a series of elements which are complementary. For me, the complementarity of man and woman in rulership is the most noteworthy. The opposing "male" and "female" principles form a whole. This tenet is present in many cultures-e.g., Yin and Yang in Taoism, opposites which complement one another to form a unified whole. The creator gods in Egypt, who initially created themselves, also embody male and female in onethey are androgynous.

Both elements, male and female, are not only opposite poles; they also embody a dynamic principle. The union of man and woman produces new life, that itself brings forth life. In my opinion, Troy's concept of duality does not comprehend the succession of generations (her "generational duality"), just as "sexual duality" is inadequate for interpreting the dichotomy of the sexes. Dynamism is the principle inherent in the succession of generations, much more so than in the "complementarity of both sexes." Generations do not stand in a dual relationship to each other; neither are they complementary. Instead they are the basis for movement, for perpetual development. Endless progression into the future is expressed by the "dynamism of generations." Troy understands Egyptian queenship to be expressed in both generations, mother and daughter, seeing them in relation to each other. In her view they form together the "generational duality." 45 But when we study rulership, the king - the ruler himself-must always be central to our inquiry. Queenship cannot be equated with rulership; rather it comprises only part of it. All lines of thought, all associations, all links proceed from or lead to the king. He is the pivot; his legitimacy and rule are central concerns. Rulership and consequently queenship

\footnotetext{
${ }^{44}$ For "complementarity," see in general von Weizsäcker 1958, Fischer/Herzka/Reich 1992. Cf. also the remarks of Baines 1984.

45 The temporal factor is important here (i.e., the generational succession mother-daughter), not consanguinity.
} 
are defined in terms of the king. Thus the "duality of generations" can only be explained starting with the king. A queen is the king's mother or the king's wife. The king's mother and the king thus form the dynamism of the generations.

The concepts complementarity and dynamism are found in Kush. This manner of thinking permeates the entire world as a natural phenomenon, for in the environment dichotomies of two complementary opposites occur time and time again. The traditional human being is shaped by the rhythm of day and night, coming into and passing out of being.

The transformation of this motif into representational form has its roots in Egyptian culture. But the adoption of forms from Egypt does not imply identity of content. The form, the image borrowed from Egypt, was imbued with Kushite content.

Kushite complementarity and dynamism as they refer specifically to queenship received their fullest expression in an antithetical representational scheme. In the lunettes of the great royal stelae (e.g., fig. 1) and on temple walls a tableau showing the king accompanied by his mother was juxtaposed antithetically to a tableau depicting him accompanied by his wife. This scheme is typically Kushite. The king presents offerings to Amun in his two primary manifestations-Amun of Karnak and Amun of Napata. Behind the king stands a woman, his mother on one side and his wife on the other. ${ }^{46}$

For me, the concepts of complementarity and dynamism can be recognized in the representations of these women. The king is shown with his mother or wife. The male and female principles, the opposites comprising a unity and guaranteeing continual renewal eternally, are immanent here in the king himself and in the women who are of primary importance for him. The "complementarity of the sexes" occupies a prominent position; the king with his essential feminine complement, signifying, as in Egypt and many other cultures, the universal principle of the continuity of life through the union of man and woman.

\footnotetext{
46 The sole exception being Kawa VIII which shows the king's mother on both sides.
}

But the "dynamism of the generations" is just as apparent in the composition. The mother of the king belongs to the previous generation, to his ancestry, while he embodies the ruling generation. The king's mother and he himself are components in "the dynamism of the generations."

Mother and wife of the king also function as two genealogical transformers. His wife, through her fertility, guaranteed the continuity of rulership; she also insured the continuation of the family of the actual king. Through the medium of his wife, the king could influence the future. She connected him with his descendants. His mother provides the link to the past, his contact with earlier generations, serving as an interface between the king and the genealogical network of his family. She is his link to the past while his wife is his link to the future. In this system, the king, anchored to the present, is connected to the historical succession of rulership by these women as the exponents of queenship.

Both these women, depicted in the lunette, also embody two levels of influence which queenship had on the king - and on the ideology of rulership. The rule of the king is based on two factors which guaranteed the durability of rulership. Barta (1975) and Assmann (1990) have dealt with these factors. These scholars began and concluded their research at different points, but they share the same central thesis. Barta (1975: 16) differentiated "rites of transmitting rulership" from "rites of exercising rulership." In the former context, the king reacts; in the latter, he acts. Assmann (1990: 208-9) distinguished the gods, who were responsible for the investiture of the king and initiating his actions, from the king, whose task was to maintain action once set in motion. Both levels - the initial and unique action of a god and the king's continual maintenance of rulership-form the basis of rulership in Kush as well as in Egypt.

The god's investiture of the king is a singular act- "initial." This unique and creative activity conditioned the continuous activity of the king as ruler. The coronation established the king once and for all as ruler. But in order to fulfill his obligations as king vis à vis the gods and humankind, he must be active, he must accomplish deeds. These included building temples, 


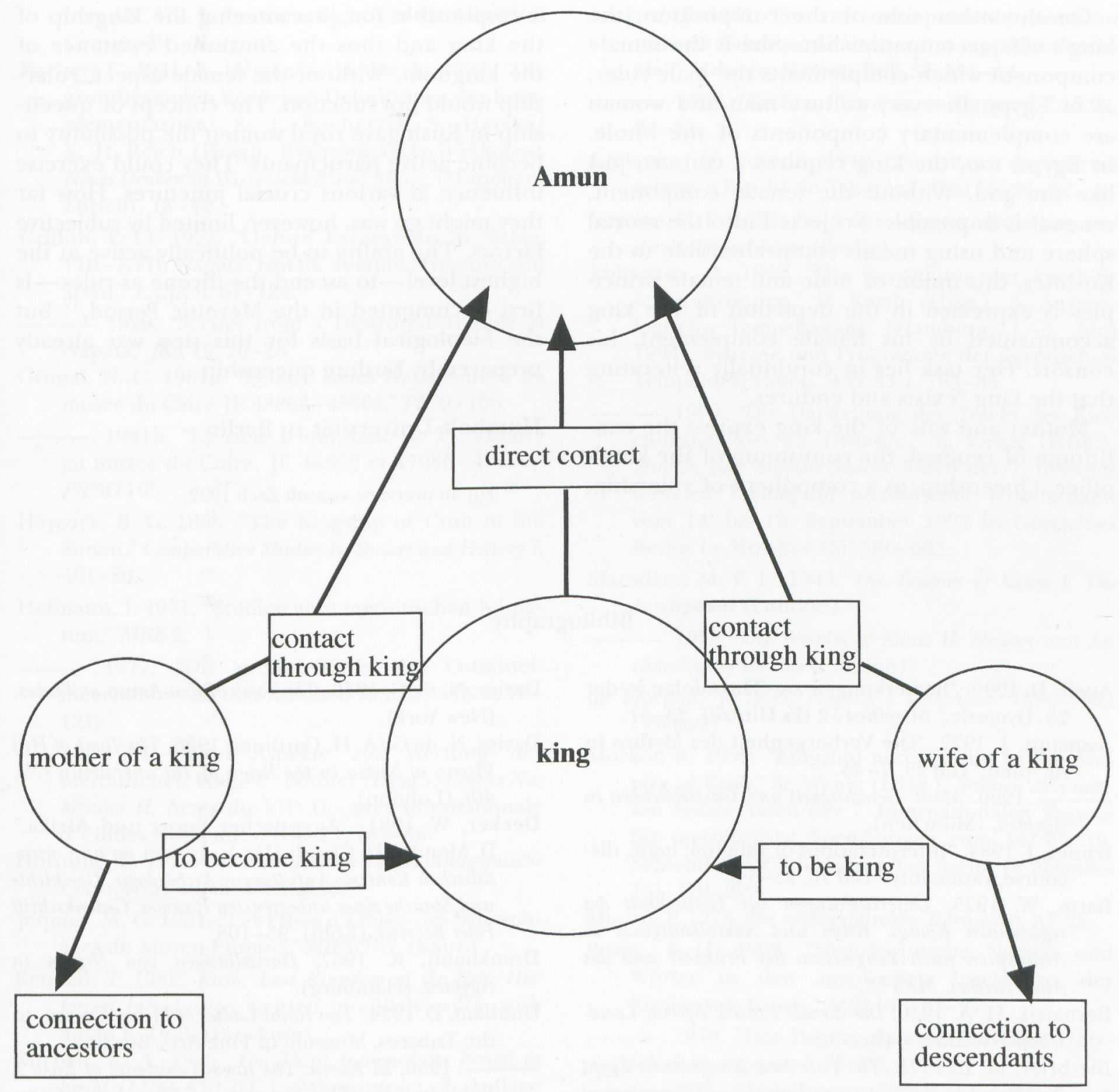

Fig. 5. Schema of queenship in Kush.

endowing them with offerings and personnel, repelling enemies, guaranteeing order in the kingdom. I propose to confront the unique occurrence of "becoming king" with the continuum of "being/remaining king."

Kushite queenship is to be integrated into this scheme (fig. 5). The antithetical composition of the lunette renders this image precisely in its Kushite manifestation. On one side, the mother of the king is shown in a manner wholly characteristic for Kush: she bears responsibility for her son's becoming king. By contrast to Egypt, her ancestry is the primary factor in determining her son's chances to become king. Furthermore, she plays an important role at the coronation. Without her ritual participation, the king cannot be crowned. She is thus the decisive factor in his "becoming king." 
On the other side of the composition, the king's wife accompanies him. She is the female component which complements the male ruler, as in Egypt. In every culture man and woman are complementary components of the whole. In Egypt, too, the king requires a consort, just like the god. Without the female component, renewal is impossible. Projected into the mortal sphere and using means comprehensible to the Kushites, this union of male and female principles is expressed in the depiction of the king accompanied by his female complement, his consort. Her task lies in continually reiterating that the king "exists and endures."

Mother and wife of the king express the continuum of renewal, the continuum of the king's office. Queenship, as a component of rulership, is responsible for guaranteeing the kingship of the king and thus the continued existence of the kingdom. Without the female aspect, rulership would not function. The concept of queenship in Kush gave royal women the possibility to become active participants. They could exercise influence at various crucial junctures. How far they might go was, however, limited by subjective factors. The ability to be politically active at the highest level-to ascend the throne as ruler-is first documented in the Meroitic Period, ${ }^{47}$ but the ideological basis for this step was already prepared by Kushite queenship.

\section{Humbolt-Universität zu Berlin}

47 For an overview, consult Zach 1992.

\section{Bibliography}

Apelt, D. 1990. "Bemerkungen zur Thronfolge in der 25. Dynastie," Meroitica 12 (Fs Hintze), 23-31.

Assmann, J. 1977. "Die Verborgenheit des Mythos in Ägypten,” GM 25, 7-43.

.. 1990. Maat. Gerechtigkeit und Unsterblichkeit in Ägypten, (München).

Baines, J. 1984. "Interpretations of religion: logic, discourse, rationality," GM 76, 25-54.

Barta, W. 1975. Untersuchungen zur Göttlichkeit des regierenden Königs. Ritus und Sakralkönigtum in Altägypten nach Zeugnissen der Frühzeit und des Alten Reiches, MÄS 32.

Bernatzik, H. A. 1930. Der dunkle Erdteil. Afrika, Landschaft-Volksleben, (Berlin).

Bierbrier, M. L. 1975. The Late New Kingdom in Egypt (c. 1300-664 B.C.). A Genealogical and Chronological Investigation (Liverpool).

Bietak, M./M. Schwarz. 1987. Nag $^{c}$ el-Scheima. Eine befestigte christliche Siedlung und andere christliche Denkmäler in Sayala-Nubien, (Wien).

Borchardt, L. 1907. "Drei Hieroglyphenzeichen," ZÄS 44, 75-79.

Brack, A./A. Brack. 1977. Das Grab des Tjanuni. Theben Nr. 74, AV 19.

Buchler, I. 1980. "The Organization of Social Life: The Perspective of Kinship Studies," I. Rossi (Hrsg.), People in Culture. A Survey of Cultural Anthropology, (NewYork), 314-98.
Davies, N. de G. 1930. The Tomb of Ken-Amun at Thebes, (New York).

Davies, N. de G./A. H. Gardiner. 1926. The Tomb of Hui Viceroy of Nubia in the Reign of Tut ankhamun (No. 40), (London).

Decker, W. 1991. "Ägyptischer Sport und Afrika," D. Mendel/U. Claudi (Hg.), Ägypten im afro-orientalischen Kontext: Aufsätze zur Archäologie, Geschichte und Sprache eines unbegrenzten Raumes. Gedenkschrift Peter Behrens, (Köln), 95-108.

Drenkhahn, R. 1967. Darstellungen von Negern in Ägypten, (Hamburg).

Dunham, D. 1924. Two Royal Ladies of Meroe, Comm. to the Trustees, Museum of Fine Arts, Boston 7. - 1950. El Kurru. The Royal Cemeteries of Kush I, Published for The Museum of Fine Arts, (Cambridge, Mass.).

- 1955. Nuri. The Royal Cemeteries of Kush II, (Boston).

1963. The West and South Cemeteries at Meroe. The Royal Cemeteries of Kush V (Boston).

Dunham, D./M. F. L. Macadam. 1949. "Names and Relationships of the Royal Family of Napata," JEA 35, 139-49.

FHN I 1994. Eide, T./ T. Hägg/R. H. Pierce/L. Török (Hrsg.), Fontes Historiae Nubiorum. Textual Sources for the History of the Middle Nile Region between the Eighth Century BC and the Sixth Cen- 
tury AD, Vol. I: From the Eighth to the Mid-Fifth Century BC (Bergen).

Fischer, E. P./H. S. Herzka/K. H. Reich. 1992. "Die grundlegenden Konzepte. Definitionen der Komplementarität,” E. P. Fischer/H. S. Herzka/ K. H. Reich (Hrsg.), Widersprüchliche Wirklichkeit. Neues Denken in Wissenschaft und Alltag, (MünchenZürich), 18-42.

Griffith, F. Ll. 1922. "Oxford Excavations in Nubia. VIII-XVII, Napata, Sanam Temple, Treasury and Town," LAAA 9, 67-124.

- 1929. "Scenes from a Destroyed Temple at Napata," JEA 15, 26-28.

Grimal, N.-C. 1981a. "Quatre stèles Napatéennes au musée du Caire JE 48863-48866,” PIFAO 106.

. 1981b. "La stèle triomphale de Pi('ankh)y au musée du Caire, JE 48862 et 47086-47089," PIFAO 105.

Haycock, B. G. 1965. "The Kingship of Cush in the Sudan," Comparative Studies in Society and History 7, 461-80.

Hofmann, I. 1971. "Studien zum meroitischen Königtum," MRE 2.

1977. "Die große Göttin des Ostmittelmeerraümes im meroitischen Reich," SAK 5, 79121.

1994. "Zwei Aspekte zur Wertung der meroitischen Frau," C. Bonnet (Hrsg.), Etudes Nubiennes II, Actes du VII ${ }^{\mathrm{e}}$ Congres internationale d'Etudes Nubiennes, (Genf), 181-86.

Hornung, E. 1971. Der Eine und die Vielen. Altägyptische Gottesvorstellungen (Darmstadt).

Jéquier, M. G. 1921. "Les Frises d'Objets des Sarcophages du Moyen Empire," MIFAO 47, (Kairo).

Kendall, T. 1982. Kush: Lost Kingdom of the Nile. Historical Introduction, written in collaboration with Susan K. Doll, (Brockton).

Kitchen, K. A. 1995. The Third Intermediate Period in Egypt (1100-650 B.C.). (Warminster), 2. Auflage mit Supplement und neuem Vorwort.

Kormysheva, E. Y. 1999. "Remarks on the Position of the King's Mother in Kush,” St. Wenig (Hrsg.), Studien zum antiken Sudan. Akten der 7. Internationalen Tagung für meroitistishe Forschungen vom 14. bis 19. September 1992 in Gosen/bei Berlin (= Meroitica 15), 239-51.

Leahy, A. 1994. "Kushite Monuments at Abydos," C. Eyre/A. Leahy/L. Leahy (Hrsg), The Unbroken Reed. Studies in the Culture and Heritage of Ancient Egypt in Honour of A. F. Shore, (London), 171-92.
Leclant, J. 1961. "Sur un contrepoids de menat au nom de Taharqa. Allaitement et 'apparition royale'," Melanges Mariette, BdE 32, 251-84.

. 1963. "Kashta, Pharaon, en Egypte," Z̈̈S 90, $74-81$.

Leclant, J./J. Yoyotte. 1949. "Nouveaux documents relatifs à l'an VI de Taharqa," Kêmi 10, 28-42.

Lepsius, C. R. 1852. Briefe aus Aegypten, Aethiopien und der Halbinsel Sinai (Berlin).

Lohwasser, A. 1995. "Die Darstellung der kuschitischen Krönung,” D. Kurth (Hrsg.), 3. Ägyptologische Tempeltagung (Hamburg, 1.-5. Juni 1994). Systeme und Programme der ägyptischen Tempeldekoration, $\ddot{A} A T$ 33.1, 163-85.

- 1999. "Die Darstellung der Tracht der Kuschitinnen der 25. Dynastie," St. Wenig (Hrsg.), Studien zum antiken Sudan. Akten der 7. Internationalen Tagung für meroitistishe Forschungen vom 14. bis 19. September 1992 in Gosen/bei Berlin (= Meroitica 15), 586-603.

Macadam, M. F. L. 1949. The Temples of Kawa I. The Inscriptions (London).

- 1955. The Temples of Kawa II. History and Archaeology of the Site (London).

de Morgan, J. 1903. Fouilles à Dahchour, 1894-1895 (Vienne).

Morkot, R. 1999. "Kingship and Kinship in the Empire of Kush," St. Wenig (Hrsg.), Studien zum antiken Sudan. Akten der 7. Internationalen Tagung für meroitistishe Forschungen vom 14. bis 19. September 1992 in Gosen/bei Berlin (= Meroitica 15), 179-229.

Munro, P. 1973. Die spätägyptischen Totenstelen, ÄF 25.

Priese, K.-H. 1968. "Nichtägyptische Namen und Wörter in den ägyptischen Inschriften der Könige von Kusch,” MIO 14: 165-91.

- 1970. "Der Beginn der kuschitischen Herrschaft in Ägypten,” ZÄS 98, 16-32.

- 1981. "Matrilineare Erbfolge im Reich von Kusch,” ZÄS 108, 49-53.

Reisner, M. B. 1931. "Inscribed Monuments from Gebel Barkal,” Z̈̈S 66, 76-100.

- 1934. "Inscribed Monuments from Gebel Barkal IV," ZÄS 70, 35-46.

Riefenstahl, L. 1976. The Last of the Nuba (London).

Robins, G. 1993. Women in Ancient Egypt (London).

Robisek, C. 1989. Das Bildprogramm des Mut-Tempels am Gebel Barkal, Veröffentlichungen der Institute für Afrikanistik und Ägyptologie 52 (Wien).

Russmann, E. R. 1974. The Representation of the King in the XXVth Dynasty, MRE 3. 
1997. "Mentuemhat's Kushite Wife (Further Remarks on the Decoration of the Tomb of Mentuemhat, 2)," JARCE 34, 21-39.

Schäfer, H. 1895. "Die äthiopische Königsinschrift des Louvre," ZÄS 33, 101-13.

1901. Die aethiopische Königsinschrift des Berliner Museums. Regierungsbericht des Königs Nastasen, des Gegners des Kambyses (Leipzig).

Staehelin, E. 1966. Untersuchung zur ägyptischen Tracht im Alten Reich, MÄS 8.

Török, L. 1986. Der meroitische Staat I. Untersuchungen und Urkunden zur Geschichte des Sudan im Altertum, Meroitica 9.

1990. "The Costume of the Ruler in Meroe: Remarks on its Origins and Significance," ANM 4, 151-202.

1995. The Birth of an Ancient African Kingdom, Kush and Her Myth of the State in the First Millennium BC, CRIPEL Suppl. 4 (Lille).

1999. "On the Foundations of Kingship Ideology in the Empire of Kush," in: St. Wenig
(Hrsg.), Studien zum antiken Sudan. Akten der 7. Internationalen Tagung für meroitistishe Forschungen vom 14. bis 19. September 1992 in Gosen/bei Berlin (= Meroitica 15), 273-87.

Troy, L. 1986. Patterns of Queenship in Ancient Egyptian Myth and History, BOREAS 14 (Uppsala).

Vernier, M. E. 1927. Bijoux et Orfeureries, CG 5200153855 (Kairo).

von Weizsäcker, C. F. 1958. Zum Weltbild der Physik (Stuttgart).

Wenig, St. 1990. "Pabatma-Pekereslo-Pekar-tror. Ein Beitrag zur Frühgeschichte der Meroiten," Meroitica 12 (Fs Hintze), 333-52.

van Wijngaarden, W. D. 1932. Beschrijving van de Egyptische Verzameling in het Rijksmuseum van Oudheden te Leiden, XVI (Leiden).

Zach, M. 1992. "Meroe: Mythos und Realität einer Frauenherrschaft im antiken Afrika,” E. Specht (Hrsg.), Nachrichten aus der Zeit. Ein Streifzug durch die Frauengeschichte des Altertums (Wien), 73-114. 